\title{
Blood pressure control and target organ complications among hypertensive patients in southern Saudi Arabia
}

M.E.K. Ahmed' and I.B. El-Awad

$$
\begin{aligned}
& \text { السيطرة على ارتفاع خغط الدم ومضاعفاته، بين المرضى في جنوب المهلكة العربية السمردية }
\end{aligned}
$$

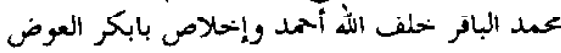

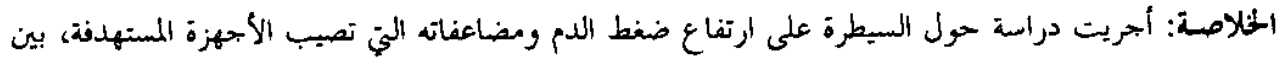

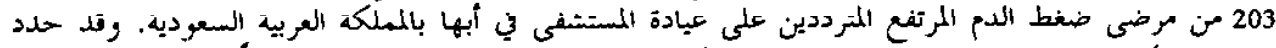

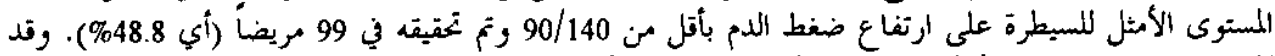

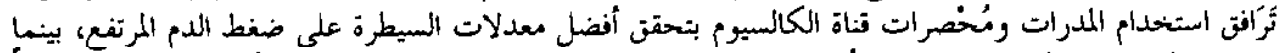

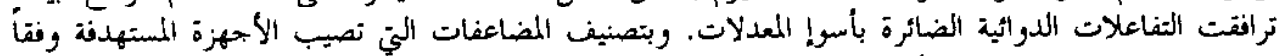

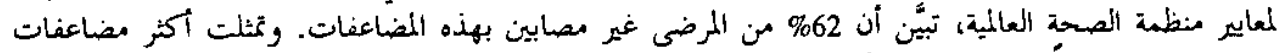

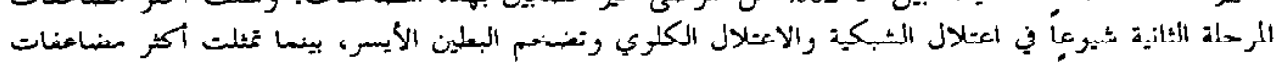

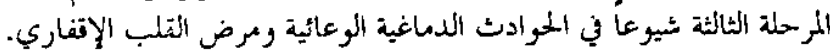

ABSTRACT Bluod pressure (BP) control and target organ complications (TOC) among 203 hypertensive patients attending a hospital clinic in Abha, Saudi Arabia were studied. Optimal BP control was defined as BP $<140 / 90$ and was achieved in 99 (48.8\%) patients. Diuretics and calcium channel biockers were associated with the best rates of BP control while adverse drug reactions were associated with the poorest rates. TOC were classified according to World Health Organization criteria; $62 \%$ of patients had no TOC. Retinopathy, renal impairment and left ventricular hypertrophy were the most common stage II complications. Cerebrovascular accidents and ischaemic heart disease were the most common stage III complications.

Contrôle de la pression artérielle et complications des organes-cibles chez des hypertendus dans le sud de l'Arabie saoudite

RESUME Le curilrôle de la pressiun ar lérietle et les compliçations des organes-cibles chez 203 hypertendus qui consultent dans un centre de soins hospitalier à Abha (Arabie saoudite) ont lait l'objet d'une étude. Le contrôle optimal de la pression artérielle a été défini comme une pression artérielle $<140 / 90$ et a été atteint chez 99 patients ( $48.8 \%$ ). Les diurétiques et les inhibiteurs calciques étaient associés aux meilieurs taux de contrôle de la pression artérielle alors que les réactions médicamenteuses indésirables étaient associejes aux plus mauvais taux. Les complications des organes-cibles étaient classées selon les critères de l'Organisation mondiale de la Santé ; $62 \%$ des patients n'avaient pas de complications des organes-cibles. La retinopathie, l'Insuffisance renale et Inypertropnte ventriculaire gauche etalent les compllcatloris de stade II les plus courantes. Les accidents vasculaires cérébraux, y compris les cardiopathies ischémiques, étaient les complications de stade lli les plus courantes.

'Depastment of Medicine, College of Medicine, King Saud University, Abha, Saudi Arabia.

2Southern Women's Society Medical Centre, Abha, Saudi Arabia.

Received: 07/05/00; accepted: $07 / 11100$

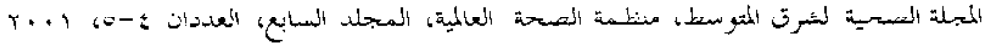




\section{Introduction}

Hypertension remains a significant but treatable public health problem in most populations worldwide [1-3], and is a major cause of cardiovascular, cerebrovascular and renal morbidity and mortality in both industrialized and developing countries $[4,5]$. In Saudi Arabia, the prevalence of hypertension varies from $2 \%$ in rural areas to $15.4 \%$ in urban communities $[6,7]$.

The risk of developing hypertensive complications varies by ethnic group. Relative to Caucasians, people of African origin experience stroke and renal failure more often and South Asians have a higher incidence of coronary heart disease $[8-10]$.

The risk of cardiovascular morbidity and fatal events is directly linked to the degree of blood pressure (BP) elevation and occurs more frequently among hypertensive individuals with evidence of target organ complications (TOC) than among those with similar BP levels without TOC $[I I, I Z]$. Furthermore, control of hypertension with antihypertensive drugs has proved to be beneficial in reducing the incidence of complications and protecting against progression to TOC and mortality $[13,14]$.

In spite of these obvious benetits and the availability of extensive guidelines, a large proportion of hypertension worldwide remains uncontrolled and therefore many individuals are at risk of serious TOC and mortality $[15,16]$.

Few studies have examined this problem in Arab countries. The present study evaluated the state of BP control and the frequency of TOC and other events among ambulatory hypertensive patients attending a hospital clinic in Abha, Saudi Arabia.

\section{Methods}

This prospective cross-sectional study was conducted among hypertensive patients attending the hypertensive clinic in a teaching hospital in Abha, southem Saudi Arabia between September 1994 and 1996. The patients were referred from primary health care centres for work-up and further management if their BP was $\geq 160 / 95 \mathrm{~mm} \mathrm{Hg}$ [World Health Organization (WHO) criteria] or if they were taking antihypertensive medication. The data were collected in a structural flowchart that included information about sociodemographic factors, duration of hypertension, results of investigations, complications, type of medication, regularity of taking medication and drug side-effects. Patients were seen initially in the clinic for assessment and request of the relevant investigations, particularly blood count, renal function tests, chest X-ray, 12-lead electrocardiogram (ECG), lipid profile and ophthalmology examination. Thereafter they were reviewed every $4-8$ weeks in the clinic by the first author who was assisted by a nurse trained in BP measurement. BP was measured in the right arm using the standard sphygmomanometer with the appropriate cuff size after the patient had been seated for at least 5 minutes. Systolic BP was recorded at phase I Korotkov's sound and diastolic BP at phase V [ 17$]$.

TOC were assessed and classified according to WHO criteria [18] by recording current and past symptoms, previous hospitalization for hypertensive complications and outcome of a detailed physical examination in the clinic, including fundal and neurological examinations. Also, further evidence of TOC was derived from the results of blood tests, such as urea and creatinine, as well as dipstick urinalysis for the detection of sugar, proteins and casts, and 
by ECG and chest X-ray for evidence of left ventricular hypertrophy. ECG-left ventricular hypertrophy was diagnosed if there was increased voltage with or without repolarization abnormalities as described in the Framingham study [ 19 ]. Evidence of cardiac ischaemia was recorded based on recognized clinical features and ECG changes [20]. Heart failure was assessed based on accepted signs and symptoms [21]. Weight and height were also measured for each patient to the nearest $0.5 \mathrm{~kg}$ and $1 \mathrm{~cm}$ respectively. Excellent BP control was recorded if the systolic and diastolic BP $_{\mathrm{s}}$ were $\leq 110 \mathrm{~mm} \mathrm{Hg}$ and $90 \mathrm{~mm} \mathrm{Hg}$ respectively [22]. Compliance with treatment was estimated by directly questioning each patient about the regularity of taking medication and the possible reasons for failure to adhere to treatment instructions $[23,24]$. Clinic attendance was recorded such that those who failed to attend more than two consecutive clinic appointments were considered noncompliant. Patients were asked to record any adverse drug reactions and to report these to the treating doctor during their clinic visits.

Data were analysed using SPSS. Simple deseriptive statistics as well as the chisquared test for categorical data and $t$-test for the differences between means were used for analysis. $P \leq 0.05$ was considered statistically significant.

\section{Results}

The sample consisted of 203 consecutive patients (mean age 46.9 years, $53 \%$ men). The majority of patients were Saudis and only $16(7.9 \%)$ were non-Saudis. Table 1 shows patient characteristics and the mean values for BPs and other variables. With direct interviewing we found that $156 \mathrm{pa}-$ tients $(77 \%)$ were compliant with

Table 1 Patient characteristics and mean values for different variables

\begin{tabular}{lcc}
\hline Variable & Value & Standard deviation \\
\hline Total no. & $\begin{array}{c}203[\mathrm{men}: 107(53 \%) \\
\text { women: } 96(47 \%)]\end{array}$ \\
Mean age & $\begin{array}{c}46.9 \text { years } \\
\text { (range } 18-75 \text { years) }\end{array}$ & 12.6 \\
Mean duration of hypertension & 4 years \\
Mean follow-up period & (range 4 months-20 years) & - \\
Mean body mass index & 8 months & 3.2 \\
Cornullanice rate & $29.3 \mathrm{~kg} / \mathrm{m}^{2}$ & 4.9 \\
Mean controlled systolic BP & $156(77 \%)$ & 12 \\
Mean controlled diastolic BP & $125 \mathrm{~mm} \mathrm{Hg}$ & 7 \\
Mean uncontrolled systolic BP & $85 \mathrm{~mm} \mathrm{Hg}$ & 12 \\
Mean uncontrolled diastolic BP & $159 \mathrm{~mm} \mathrm{Hg}$ & 8 \\
\hline BP = Djood pressure. & $102 \mathrm{~mm} \mathrm{Hg}$ &
\end{tabular}

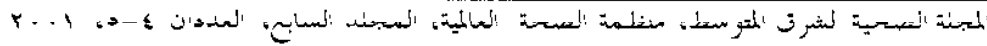


medications; the majority of those $(68 \%)$ were males.

For slightly less than two-thirds $(62.1 \%)$ of the patients, no TOC were detected $[18]$; the spectrum and the frequencies of WHO stage II and stage III TOC events are shown in Table 2 . Mild retinopathy $(21.6 \%)$, albuminuria (15.1\%), elevation of urea $>50 \mathrm{mg} / \mathrm{dL}(12.9 \%)$, creatinine $>1.5 \mathrm{mg} / \mathrm{dL}(10.8 \%)$ and left ventricular hypertrophy $(10.3 \%)$ were the most common stage II complications. Transient ischaemic attacks and strokes (9.2\%) were the most frequent stage III complication followed by congestive heart failure $(5.4 \%)$, overt renal failure $(4.8 \%)$. When patients were classified according to sever-

Table 2 Frequency of target organ damage (TOD) among 203 hypertensive patients

\begin{tabular}{lrr}
\hline Stage of TOD & No. & $\%$ \\
\hline Patients without TOD & 126 & 62.1 \\
Patients with TOD & 77 & 37.9 \\
Stage II TOD & & \\
$\quad$ Total no. of complications \\
Creatinine $>1.5$ mg/dL & 131 & \\
Urea $>50$ mg/dL & 20 & 10.8 \\
ECG left ventricular hypertrophy & 24 & 12.9 \\
Albuminuria & 19 & 10.3 \\
Narrowing of retinal arteries & 28 & 15.1 \\
Stagelll TOD & 40 & 21.6 \\
$\quad$ Total no. of events & & \\
Cerebrovascular accidents & 50 & \\
TIA or strokes & & \\
Angina & 17 & 9.2 \\
Myocardial infarction & 4 & 2.2 \\
Congestive heart failure & 7 & 3.8 \\
Ronal failurc & 10 & 5.4 \\
Fundal haemorrhages and exudates & 9 & 4.8 \\
Papilloedema & 1 & 0.5 \\
\hline
\end{tabular}

asome patients had more than one complication/ event.

$E C G$ = electrocardiograph.

$T I A=$ transient ischaemic attacks. ity of hypertension, there was a significantly higher frequency of TOC and complications among patients with systolic and diastolic $\mathrm{BP}>140 \mathrm{~mm} \mathrm{Hg}$ and $90 \mathrm{~mm} \mathrm{Hg}$ respectively.

As regards treatment, 69 patients $(34 \%)$ needed more than one drug to control their BP. The most common drugs prescribed in accordance with published guidelines [I], either alone or in combination, were atenolol $(34 \%)$, indapamide $(28 \%)$, angiotensin-converting enzyme inhibitors ( $18 \%$ ) and calcium channel blockers, primarily nifedipine (15\%). Other drugs used infrequently included thiazide diuretics and methyldopa. Optimal BP control $(\leq 140 / 90$ $\mathrm{mm} \mathrm{Hg}$ ) was achieved in only 99 patients $(48.8 \%)$ with no significant difference between men and women or between Saudis and non-Saudis. Patients treated with indapamide and diuretics achieved the best BP control $(67.6 \%)$, followed those treated with calcium channel blockers $(60.0 \%)$, beta-blockers $(55.0 \%)$ and angiotensinconverting enzyme inhibitors (37.5\%) (Table 3 ). Analysis of the factors that might have contributed to neglect of treatment and non-optimal BP control revealed that adverse drug effects, particularly impotence, fatigue and headache were the most common causes followed by poor patient compliance and treatment failure (drug not leading to significant BP control after at least 2 months of treatment). Hypotensive medications were changed if significant side-effects or treatment failure occurred.

\section{Discussion}

This study determined the degree of BP control and the spectrum of target organ involvement among hypertensive patients attending a hospital clinic in Abha, southern Saudi Arabia. Although much concern has 
Table 3 Rates of optimal blood pressure control $(\leq 140 / 90 \mathrm{~mm} \mathrm{Hg})$ according to type of medication

\begin{tabular}{|c|c|c|c|}
\hline Medication & Total no. & No. controlled & $\%$ \\
\hline Indapamides and thiazides & 37 & 25 & 67.6 \\
\hline $\begin{array}{l}\text { Calcium channel blockers } \\
\text { (mainly nifedipine) }\end{array}$ & 20 & 12 & 60.0 \\
\hline Beta-blockers (atenolol) & 49 & 27 & 55.0 \\
\hline $\begin{array}{l}\text { Angiotensin-converting } \\
\text { enzyme inhibitors }\end{array}$ & 24 & 9 & 37.5 \\
\hline Two or more drug combinations & 69 & 26 & 37.5 \\
\hline \multicolumn{4}{|c|}{ 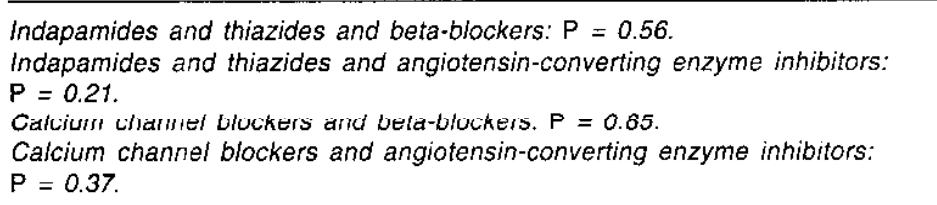 } \\
\hline
\end{tabular}

been expressed about the failure to attain optimal BP control in industrialized countries [22], the situation in developing countries is expected to be no better. Only $48.8 \%$ of our pationts had achicved optimal BP control. Control rates of $46 \%$ in Sudan, $53 \%$ in the United Kingdom and 14\%-25\% in the United States of America have been reported [23-27], but only $8 \%$ achieved target $\mathrm{BP}$ control in Egypt [28]. Although not optimal, the rate of $\mathrm{BP}$ control among our patients was better than that reported from other nations. Perhaps this was because the group of referred patients in the present study received extended care in a specialized clinic run by physicians and were more compliant with medication. On the other hand, however, one might argue that our referred patients represented more difficult to control hypertension since more than a third $(37.8 \%)$ needed combination therapy for the treatment of their hypertension.

The reasons for failure to achieve optimal BP control vary by nation. In our study and in a previous report [20], adverse drug reactions, in particular impotence generally caused by beta-blockers and diuretics, constituted the main reason for non-optimal BP control. However, in sharp contrast, poor patient compliance was the main reason for poor BP control in the United Kingdom, France and Italy, while drug side-effeets were the third reason [15]. Our findings emphasize the crucial issue of maintaining quality of life, in particular well-being and sexual activity, when treat ing hypertensive patients [30]. Moreover, in developing countries, additional causes such as scarce resources, other health pri orities, life stresses [16], and lower levels of public health education also contribute to the failure to achieve optimal BP control. Disturbing rates of BP control as low as $4.2 \%$ and $3.3 \%$ have been reported from China and india respeetively [31,32]. Mancia et al. demonstrated in a recent study that office $\mathrm{BP}$ recording cannot be blamed for poor BP control as poor control was observed even when the values were based on ambulatory blood pressure recording [33]. Furthermore, the risk of TOC corre-

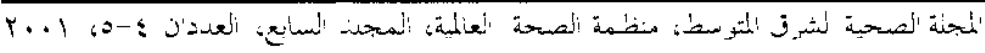


lates well with $t$ - ievels of BP achieved but the development of evidence of TOC confers an increased cardiovascular risk at any BP level.

The pattern of TOC in this study was slightly different from that previously reported from Sudan and other African countries because of a higher frequency of cardiovascular complications in the Saudi population: it was also distinct from the spectrum in India where coronary heart disease was far more prevalent [34-36].

We found a low prevalence of severe retinopathy (grades III and IV) armong Saudi patients, which was nonetheless higher than anticipated. This observation was interesting since the rarity of this advanced type of retinopathy among non-Caucasians has previously been reported by several workers [34-37]. The exact explanation for this finding is unclear but it may be attributed to the inaccuracy of routine ophthalmoscopic assessment of the retina or it may represent a distinct ethnic difference between Caucasians and non-Caucasians.

An emerging serious trend in the pattern of hypertensive TOC in Saudi Arabia is the increasing prevalence of cardiovascular disease, which is most often attributed to changes in sociodietary factors that followed the improved economy. This was demonstrated in our study. If all cardiovascular complications were pooled together (angina, myocardial infarction, congestive heart failure and left ventricular hypertrophy), their prevalence rate exceeded that of renal disease and stroke. This is different from Japan and China where strokes have been found to be more common than cardiac complications among hypertensive individuals $[31,32]$.

Based on our results, we believe that the delivery of care for hypertensive patients should be intensified in order to control BP better and to prevent TOC and mortality from hypertension. This requires collaboration and communication between primary and secondary health care facilities on one side and the physician and patients on the other. Moreover, the prevention of TOC implies early detection of hypertension and optimal use of treatment guidelines, even though some may seem to be too complex or too theoretical to be used in clinical practice $[1,13]$.

\section{References}

1. Joint National Committee on Detection, Evaluation and Treatment of High Blood Pressure. The fifth report of the Joint $\mathrm{Na}$ tional Committee. Archives of internal medicine, 1993, 153:154-87.

2. Muna WFT. Cardiovascular disorders in Africa. World health statistics quarterly, 1993. 46(2):125-33.

3. Whelton IK. Epidemiology of hypertension. Lancet, 1994, 344:101-16.

4. Sempos $\mathrm{C}$ et al. Divergence of the recent trends in coronary mortality for the four major race-sex groups in the
United States. American journal of public health, 1988, 73:1422-7.

5. Alwan AAS. Cardiovascular diseases in the Eastern Mediterranean region. worlo health statistics quarterly, 1993 , 46(2):97-100

6. Khalid ME et al. Pattern of blood pressures among high and low altitude residents of southern Saudi Arabia. Journal of human hypertension, 1994, 8:765-9.

7. Saeed AW et al. Prevalence of hypertension and sociodemographic characteristics of adult hypertensive in Riyadh

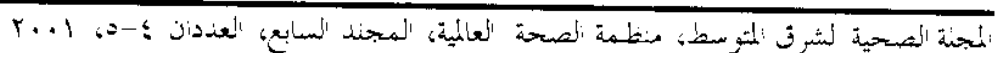


City, Saudi Arabia. Journal of human hypertension, 1996, 10:583-

8. Cappucclo FP. Ethnicity dind cardiovascular risk: variations in people of African ancestry and South Asian origin. Journal of human hypertension, 1997, 11:5716.

9. Wild S, McKeigue P. Cross-sectional anlalysis of mortality by country of birth in England and Wales, 1970-1992. British medical journal, 1997, 314:705-10.

10. Reddy KS. Cardiovascular disease in India. World health statistics quarterly, 1993, 46(2):101-7.

11. Flack JM et al. Ethnicity and renal disease: lessons from the Multiple Risk Factor Intervention Trial and Treatment of Mild Hypertension Study. American journal of kidney disease, 1993, 21(4 suppl. 1):31-40.

12. Kannel WB, Dannenberg AL, Levy $D$. Population implications of electrocardiographic left ventricular hypertrophy. American journal or caralology, 1987 , 60:851-931.

13. Medical Research Council Working Party. MRC trial of treatment of mild hypertension. Principal results. British medical journal of clinical research, 1985, 291:97-104.

14. Management Committee. The Australian therapeutic trial in mild hypertension. Lancet, 1980, 1(8181):1261-7.

15. Menard J, Chatellier G. Limiting factors in the control of BP: why is there a gap between theory and practice? Journal of human hypertension, 1995, 9:519-23.

16. Joshi PP, Salkar RG, Heller RF Determinants of poor blood pressure control in urban hypertensives of central India. Journal of human hypertension, 1996 , 10:299-303.
17. Petrie $\mathrm{JC}$ et al. Recommendation on blood pressure measurement. British medical journal, 1986, 293:611-5.

18. Hypertension control. Geneva, World Health Organization, 1996:27-31 (WHO Technical Report Series. No. 862)

19. Levy D, Salomon M, D'Ayostino AJ. Prognostic implication of baseline electrocardiographic features and their serial changes in subjects with left ventricular hypertrophy. Circulation, 1994, 90:178693

20. Hypertension control. Geneva, World Health Organization, 1996:33-5 (WHO Technical Roport Sorios, No. 862).

21. Guidelines for the diagnosis of heart failure. The task force on heart failure of the European Soclety of Cardlology. European heart journal, 1995, 16:741-51.

22. Hanson L, Zanchetti A. The Hypertension Optimal Treatment (HOT) study patient characteristics, randomization, risk profiles and early blood pressure resuits. Blood pressure, 1994, 3.322-7.

23. Lusscher TF. Antihypertensive therapy and compliance. Internist, 1988, 29:279-84.

24. Balazovjech I, Hnilica P. Compliance with antihypertensive treatment in consultation rooms for hypertensive patients. Joumal of human hypertension, 1993, 7:581-3.

25. Hussain AA, Elzubier AG, El-Bagir AM. Target organ involvement in hypertensive patients in eastern Sudan. Journal of hypertension, 1989, 13:9-12.

26. Sever $P$. The continuing challenge of hypertension. Journal of human hypertension, 1995, 9(suppl. 2):S49-51.

27. Burt VL et al. Trends in prevalence, awareness, treatment and control of hy pertension in the adult US population. Data from the health examination sur- 
veys, 1960 to 1991 . Hypertension, 1995, 26:60-9.

28. Ihrahim MM et al. Hypertension, prevalence, awareness, treatment and control in Egypt. Results from the Egyptian National Project. Hypertension. 1995. 26:886-90.

29. Khalil SA, Elzubier AG. Drug compliance among hypertensive patients in Tabuk, Saudi Arabia. Journal of hypertension, 1997, 15:561-5.

30. Croog SH et al. The effects of antihypertensive therapy on the quality of life. New England journal of medicine, 1986 , 314:1657-64.

31. Lisheng L. Hypertension control in China. High blood pressure, 1995, 4:67-0.

32. Reddy KS. Hypertension control in developing countries: generic issues.
Journal of human hypertension, 1996, 10(suppl.):533-8.

33. Mancia $G$ et al, Blood-pressure control in the hypertensive population. Lancet, $1997,349: 454-7$.

34. Mensan GA, Bakley NL, Cooper RS. Spectrum of hypertensive organ damage in Africa: a review of published studioe. Journal of human hypertension, 1994, 8:799-808.

35. Ahmed ME. The clinical presentation of hypertension in Sudan. Ethnicity and disease, 1991, 1:288-91.

36. Gopinath $\mathrm{N}$ et al. A 3-year follow-up of hypertension in Delhi. Bulletin of the World Health Organization, 1994, 72(5):715-20.

37. Akinkugbe 00 . The rarity of hypertensive retinopathy in the African. American jour$\mathrm{nal}$ of medicine, 1968, 45:401-4. 